\title{
New products and services briefing
}

The new products and services listed below were selected by the editors based on potential interest to JAOA's readers. Listings are prepared from information supplied by the companies cited or by their agents and are presented for informational value only. Publication in no way constitutes endorsement or warranty by THE JOURNAL OF THE AMERICAN OSTEOPATHIC ASSOCIATION or by the American Osteopathic Association. In contacting the companies, please mention JAOA.

\section{Ovarian cancer drug}

Paraplatin $^{\otimes}$ (carboplatin JM-8), intended for treatment of recurrent ovarian cancer, is available in 50$\mathrm{mg}, 150-\mathrm{mg}$, and 450 -mg vials. Common side effects-kidney toxicity, nausea, and vomiting-generally don't occur with this treatment. Concomitant high-dose antiemetic treatment and the need for extensive hydration are not required with this product. For more information, contact Bristol-Myers Oncology Division, 2404 W Pennsylvania St, Evansville, IN 47721; (812) 429 5000 .

\section{Low-calorie cholesterol- lowering powder}

Questran ${ }^{\otimes}$ Light (cholestyramine) powder has 1.6 calories per packet or scoop. A single dose of the cholesterol-lowering agent must be mixed in 2 or $3 \mathrm{oz}$ of water or other noncarbonated beverage or even highly fluid soups or high-moisture fruits like applesauce or crushed pineapple. This cholestyramine features $\mathrm{Nu}$ trasweet ${ }^{\circledR}$ and $44 \%$ less powder per dose than the regular formula. For more information, contact Bristol-
Myers US Pharmaceutical and Nutritional Group, Evansville, IN 47721; (812) 429-5000.

\section{Orthopedic leg walker}

Featuring adjustable straps with contact closures offering controlled compression and stability, the DePuy Walker is available in fixed and adjustable styles. Limited or fixed dorsiflexion; limited or fixed plantar flex-

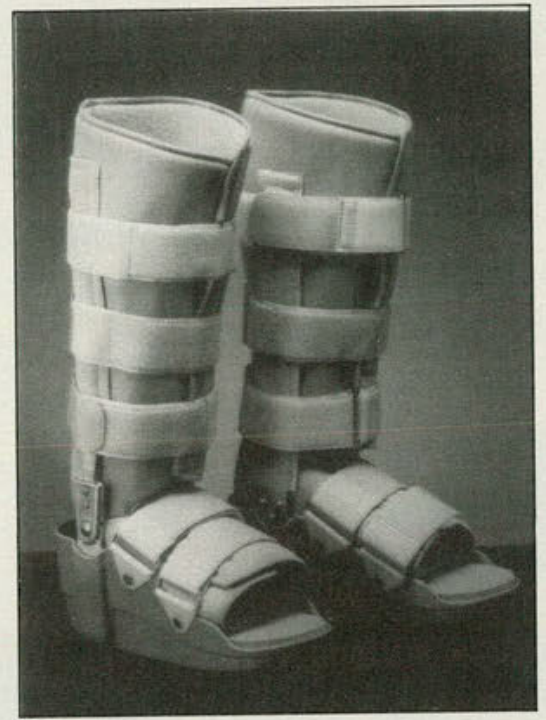

ion; and neutral or free motion may be achieved with the adjustable-style walker. The fixed style features neutral motion only. For more information, contact DePuy, PO Box 988, Warsaw, IN 46580; (219) 267-8143.

\section{Drug-delivery system}

The multichannel electronic LifeCare ${ }^{\circledast} 5000$ drug-delivery system features six programmable modes. Each can deliver primary fluids, intravenous solutions, tube feedings, and blood. Rates and dosages are programmable as well. For more information, contact Abbott Laboratories, Abbott Park, IL 60064; (312) 937-7069.

\section{Lipid analyzer}

The in-office CLA/200 ChemPro Lipid Analyzer determines total cholesterol, HDL, and triglyceride levels using dual functional buttons to direct the single well filter photometer. Assays take less than $20 \mathrm{~min}$ utes to perform. For more information, contact Johnson \& Johnson Professional Diagnostics, Inc, Rt 202, Raritan, NJ 08869; (800) 338-1643.

\section{Medical waste-disposal system}

MedServe Waste Control System provides sealed waste containers, pick up and delivery, and full location and disposal tracking information. The service, which operates its own thermal treatment destruction facility, serves hospitals and clinics in Oklahoma, Arkansas, Missouri, and Kansas. For more information, contact MedServe ${ }^{\sqrt{1 x}}$, Inc, PO Box 700864, Tulsa, OK 74170-0864; (918) 744-4311.

\section{Teaching, pediatric stethoscopes}

The Flexiscope ${ }^{\sqrt{3}}$ line of stethoscopes now features devices designed for pediatric and teaching use. Both have the Delrin ${ }^{\star}$ headpiece to minimize interference. The pediatric model is available with straight or coiled sound tubing; the teaching model (continued on page 674) 


\section{OBESITY.}

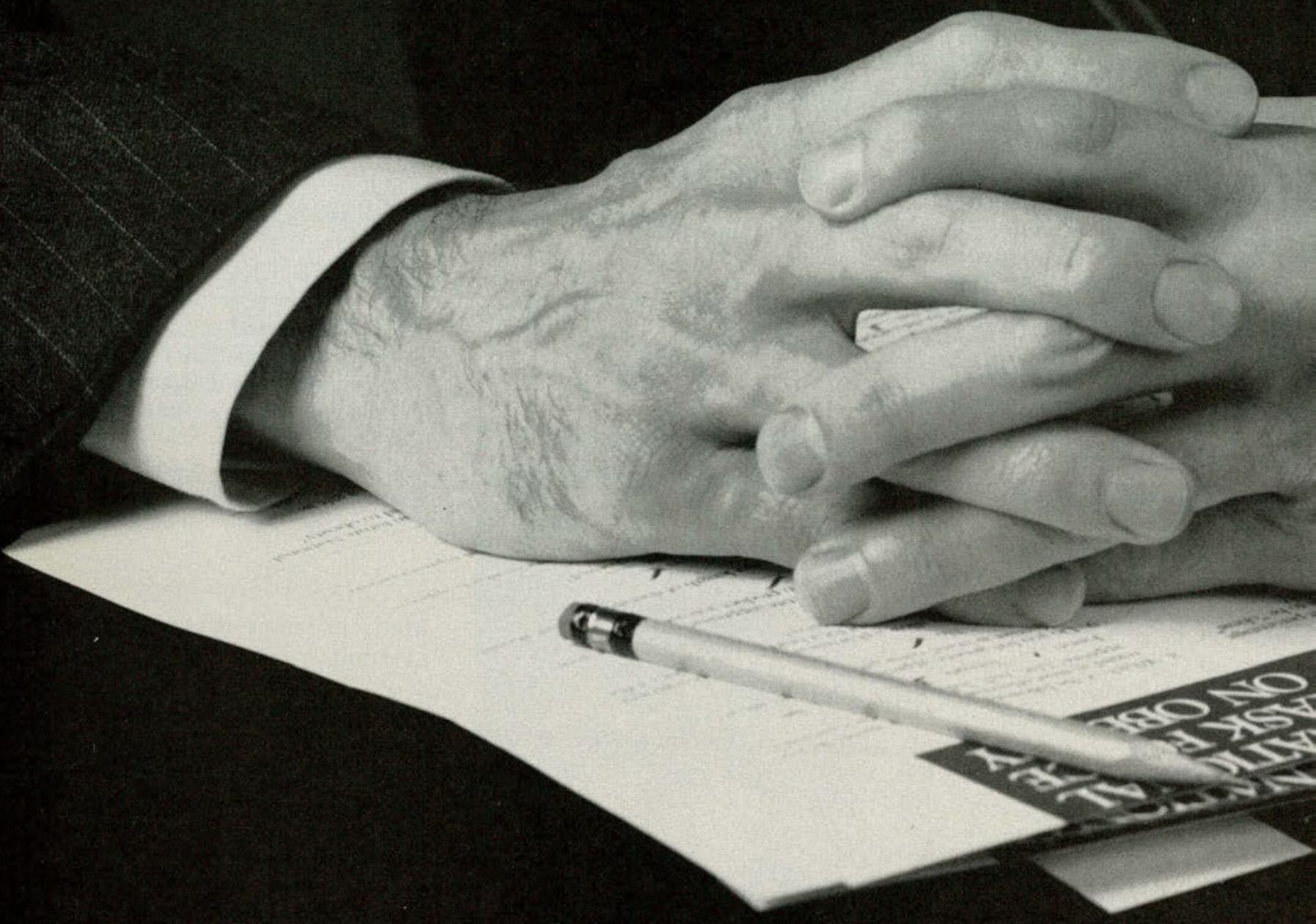

According to responses from over 6,800 physicians, obesity has become a serious health threat.

A problem so significant ... $77 \%$ of responding physicians view it as the single most prevalent chronic condition in the US.'
A problem so widespread ... $88 \%$ of physicians realize it afflicts at least 1 out of 3 American adults. ${ }^{1.2}$

$A$ "disease" so serious ... $81 \%$ of physicians acknowledge it is related. either directly or indirectly, to $20 \%$ or more of the nation's mortality. ${ }^{1.3}$ 


\section{NATIONWIDE URPRISE YOU.}

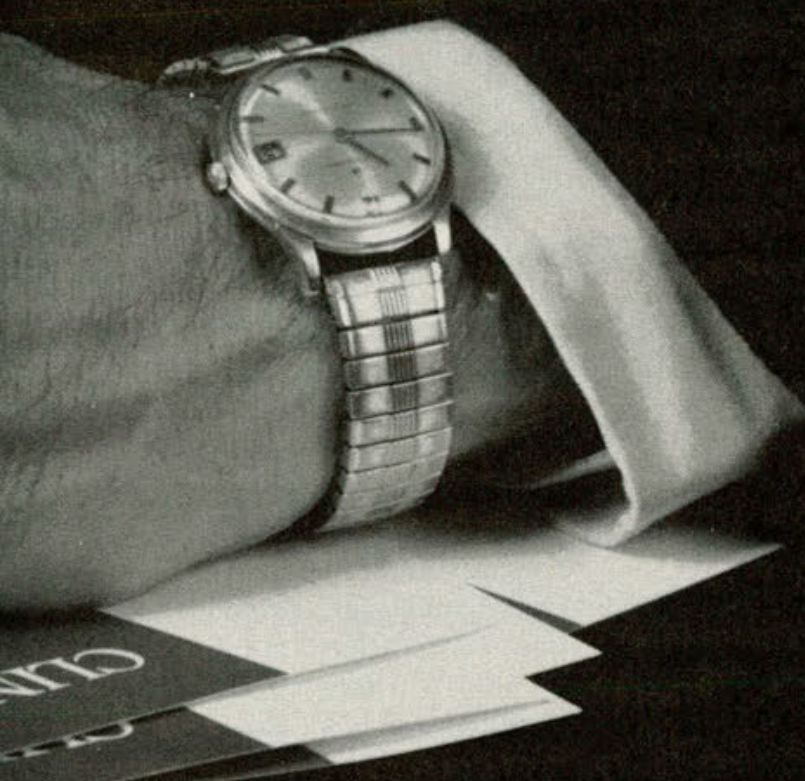

FASTIN $^{\circledR}$ (phentermine HCl) can help. It effectively curbs hungerthe critical first step. In fact, $46 \%$ of responding physicians prefer FASTIN over two other well-known anorectics.

As an adjunct to prescribed diet, exercise, and counseling, FASTIN can help provide the early motivation many patients need to overcome obesity .... and its serious health risks.

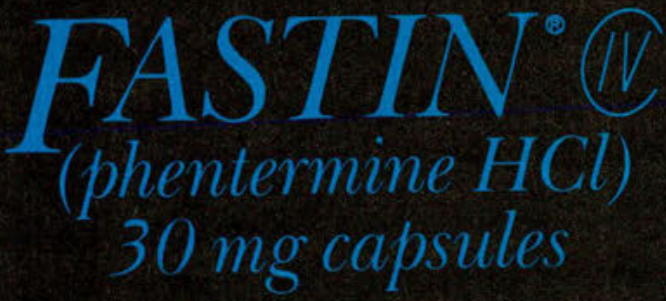

Preferred by physicians over other well-known anorectics. ${ }^{1}$

Please see summary of prescribing information on next page.

References: responding physicians answered all questions). Data on file, Beecham responding phys

. Weiss ST: Obesity: Pathogenesis, consequences, and approaches to treatment. Psychiatr Clin North Am 1984,7:307-319.

treatment. (S) $\$$. 30.6 billion a year. . Eastman P. Call obesity "a killer", cos 


\section{$\operatorname{FASTIN}^{\bullet} \mathbb{\mathbb { N }}$ \\ (phentermine $\mathrm{HCl}$ ) \\ 30 mg capsules}

\section{Preferred by physicians over otherwell-known anorectics.'}

Briet Summary

indicated only for use as a short-term adjunct in the management of exoge-

INDICATION: FASTIN is indicated in the management of erogenous obesity as a short-term (a few weeks) adjunct in a regimen of weight reduction based on hould be measured against possible risk factors inherent in their use such as those described below

CONTRAIMDICATIONS: Advanced arteriosclerosis, symotomatic cardiovascular disease, moderate to severe hypertension, hyperthyroudism, known hypersensi. fivity, or idiosyncrasy to the sympathomimetic amines, glaucoma

Agitated states. Patients with a history of drug abuse. During or within 14 days following the administration of monoamine oxidase inhibitors (hypertensive crises may result.

WARNINGS: Tolerance to the anorectic effect usually develops within a few weeks. When this occurs, the recommended dose should not be exceeded in

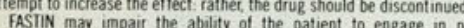

hazardous activities such as operating machinery or driving a motor vehicle. the patient should therefore be cautioned accordingly.

DRUG DEPENDENCE: FASTIN is related chemically and pharmacologically to the amphetamines. Amphetamines and related stimulant drugs have been atensively abused, and the possibility of abuse of FASTIN should be kept in mind when evaluating the desirability of including a drug as part of a weight reduction program. Abuse of amphetamines and related drugs may be associated with intense psschological dependence and severe social dystunction. There are reports of patients who have increased the dosage to many times istration results in extreme fatigue and mental depression changes administration results in extreme fatigue and mental depression. changes are also drugs include severe dermatoses, marked insomnia, irritability, hyperactivity. and personality changes. The most severe manifestation of chronic intoxica. tions is psychosis, often clinically indistinguishable from schizophrenia Usage in Pregnancy: Safe use in pregnancy has not been established. Use of AASIiN by women who are or who may become pregnant, and those in the first trimester of pregnancy, requires that the potential benefit be weighed against the possible hazard to mother and infant

sage in Children: FASTIN is not recommended for use in children under 12 years of age

sage with Alcohol: Concomitant use of alcohol with FASTIN may result in an PRECAUTIO ins. Caution is

ion is to be exercised in prescribing FASTIN for patients the even mild hypertension.

Insulin requirements in diabetes mellitus may be altered in association with e use of FASTIN and the concomitant dietary regimen.

AStiN may decrease the hypotensive effect of euanethidine

The least amount feasible should be prescribed or dispensed at one time in order to minimize the possibility of overdosage

ADVERSE REACTIONS: Cardiovascular: Palpitation, tachycardia, elevation of blood pressure.

Centrai hervous System: Overstimulation, restlessness, diziness, insomia euphoria, dysph sit Gastrointestinat

tinal: Dryness of the mouth, unpleasant taste, diarnhea, constipation, other gastrointestinal disturbances.

Aliergic: Unticana.

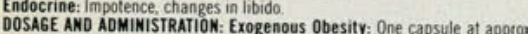
mately 2 hours after breaktast for appetite control. Late evening medication should be avoided because of the possibility of resulting insomnia. Administration of one capsule $(30 \mathrm{mg})$ daily has been found to be adequate in depression of the appetite for twelve to fourteen hours

FASTIN is not recommended for use in children under 12 years of age

OVERDOSAGE: Manifestations of acute overdosage with phentermine include restlessness, tremoc, hyperreflexia, rapid respiration, confusion, assaultive ness, hal sucinations, pancic staces. Faligue and depression usually follow the or hypotension and circulatory collapse. Gastrointestinal symotoms inclune nausea. vomiting diarthea, and abdominal cramps. Fatal poisoning usually terminates in convulsions and coma

Management of acute phentermine intoxication is largely symotomatic and includes lavage and sedation with a barbiturate. Expenience with hemodialysis or peritonear dialysis is inadequate to permit recommendations in this regard Acidification of the urine increases phentermine excretion. Intravenous phentolamine (REGIIINE) has been suggested for possible acute, severe hypertension, if this complicates phentermine overdosage.

out prescription.

capsules with blue and white beads containing $30 \mathrm{mg}$ phentermine hydrochloride (equivalent to $24 \mathrm{mg}$ phentermine)

NDC 0029-2205-39

\section{Beecham}

\section{laboratories}

Bristol, Tennessee 37620

\title{
New products and services briefing
}

\author{
(Continued)
}

has straight sound tubing only. For more information, contact CMT Medical Products, PO Box 210173, South Euclid, OH 44121; (800) 634-6445.

\section{Metoclopramide syrup}

Sugar-free, sodium-free, and alcoholfree metoclopramide syrup delivers $5 \mathrm{mg} / 5 \mathrm{~mL}$ per bottled-dose. Accompanying patient cups deliver $10 \mathrm{mg} /$ $10 \mathrm{~mL}$ per dose. For more information, contact Roxane Laboratories, PO Box 16532, Columbus, OH 43216; (614) 276-4000.

\section{Nasal spray for diabetics}

Intended for patients with central diabetes insipidus, The DDAVP ${ }^{\circledR}$ (desmopressin acetate) nasal spray is available in a metered-dose spray bottle. The nasal spray contains a synthetic analog of the antidiuretic hormone vasopressin. Dose-related adverse reactions include headache, nausea, nasal congestion, rhinitis, flushing, and mild abdominal cramps. For more information, contact Rorer Pharmaceuticals, 500 Virginia Dr, Fort Washington, PA 19034; (215) 628-6000.

\section{Temperature indicator}

The 1-sq in Temp'Trend ${ }^{\circledR}$ II indicates core temperatures as measured by an oral thermometer. The device measures temperatures of $93^{\circ} \mathrm{F}$ to $107^{\circ} \mathrm{F}$. Worn on the patient's forehead, the indicator monitors postoperative conditions. For more information, contact Kiyota International, Inc, 724 W Algonquin Rd, Arlington Heights, Il 60005; (312) 956-0471. 

The \#1 prescribed allergy in the U.S. and worldw

*

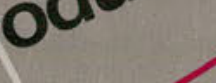

RAPID,

UNSURPASSED RELIEF

Relief starts fast - most hay fever patients experience significant relief within 1 hour $^{1+}$

Relief peaks fast - within 3-4 hours ${ }^{2 * \star}$

Relief is unsurpassed — proven in 30 double-blind clinical studies ${ }^{3-7}$

Relief is convenient - for high patient compliance ${ }^{t \dagger}$

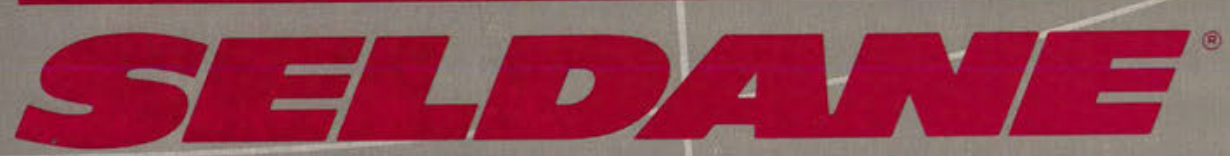

(terfenadine) 60 mg tablets BID

for seasonal allergic rhinitis

\section{The ideal profile for fast, on-the-job relief}

- Based upon worldwide prescription and distribution information (1986-1988)-data on file.

$\uparrow$ In most hay fever patients $(55 \%)$.

* In studies using the histamine-induced skin wheal test

$+\uparrow$ A summary of 26 studies relating compliance and dosage schedules of various types of medications showed no significant difference in compliance rates between q.d. and b.i.d. dosing. There was significantly greater compliance with q.d. or b.i.d. dosing compared to ti.i. or q.i.d. dosing $(p<0.05)$ :

C) 1989. Merrell Dow Pharmaceuticals Inc.

Before prescribing Seldane, please see Brief Summary of Prescribing Information, which appears on the reverse side. 

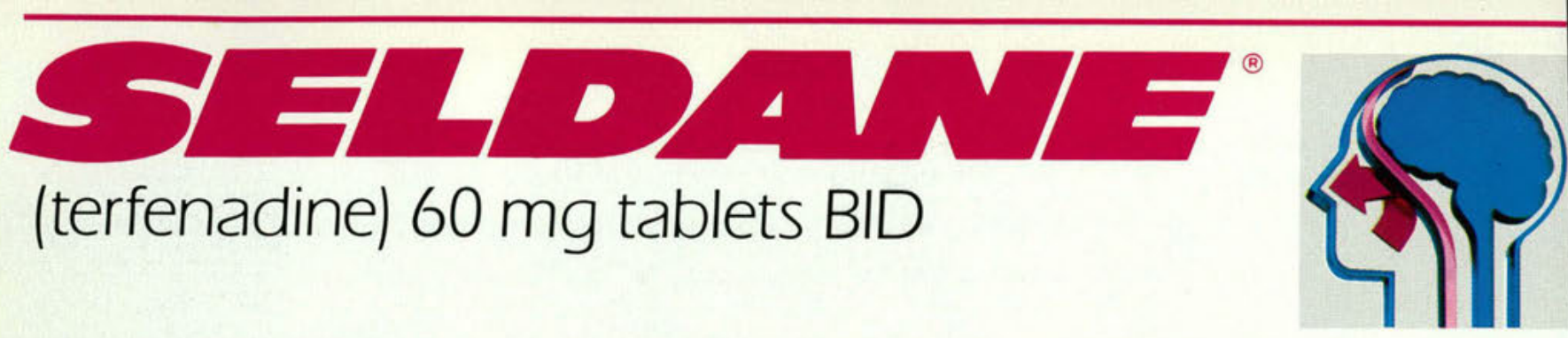

- Fast, unsurpassed relief

- Efficacy maintained in through-the-season use-11 - Lets patients stay alert so they can perform at their best

\section{- B.i.d. dosing for high patient compliance}

\section{Seldane ${ }^{\circledR}$ (terfenadine) $60 \mathrm{mg}$ Tablets \\ BRIEF SUMMARY}

CAUTION: Federal law prohibits dispensing without prescription.

DESCRIPTION

Seldane (terfenadine) is available as tablets for oral administration. Each tablet contains $60 \mathrm{mg}$ terfenadine. Tablets also contain, as inactive ingredients: corn starch, gelatin, lactose, magnesium stearate, and sodium bicarbonate.

INDICATIONS AND USAGE

Seldane is indicated for the relief of symptoms associated with seasonal allergic rhinitis such as sneezing, rhinorrhea, pruritus, and lacrimation.

CONTRAINDICATIONS

dients.

\section{PRECAUTIONS}

Information for patients

Patients taking Seldane should receive the following information and instructions. Antihistamines are prescribed to reduce allergic symptoms. Patients should be questioned about pregnancy or lactation before starting Seldane therapy, since the drug should be used in pregnancy or lactation only if the potential benefit justifies the potential risk to fetus or baby. Patients should be instructed to take Seldane medication in a tightly closed container in a cool, dry place, away from heat or direct sunlight, and away medication in
from children.

Carcinogenesis, mutagenesis, impairment of fertilit

Carcinogenesis, mutagenesis, impairment of fertility
Oral doses of terfenadine, corresponding to 63 times the recommended human daily dose, in mice for 18 Oral doses of terfenadine, corresponding to 63 times the recommended human daily dose, in mice for 18
months or in rats for 24 months, revealed no evidence of tumorigenicity. Microbial and micronucleus test assays with terfenadine have revealed no evidence of mutagenesis.

Reproduction and fertility studies in rats showed no effects on male or female fertility at oral doses of up to 21 times the human daily dose. At 63 times the human daily dose there was a small but significant reduction in implants and at 125 times the human daily dose reduced implants and increased post-implantation losses were observed, which were judged to be secondary to maternal toxicity.

Pregnancy Category C

There was no evidence of animal teratogenicity. Reproduction studies have been performed in rats at doses 63 times and 125 times the human daily dose and have revealed decreased pup weight gain and survival when terfenadine was administered throughout pregnancy and lactation. There are no adequate and well-controlled studies in pregnant women. Seldane should be used during pregnancy only if the potential benefit justifies the potential risk to the fetus.

Nonteratogenic effects

Seldane is not recommended for nursing women. The drug has caused decreased pup weight gain and survival in rats given doses 63 times and 125 times the human daily dose throughout pregnancy and lactation. Effects on pups exposed to Seldane only during lactation are not known, and there are no adequate and well-controlled studies in women during lactation.

Pediatric use

Safety and effectiveness of Seldane in children below the age of 12 years have not been established.

General Consideration should be given to potential anticholinergic (drying) effects in patients with lower airway
disease, including asthma.

\section{ADVERSE REACTIONS}

Experience from clinical studies, including both controlled and uncontrolled studies involving more than 2,400 patients who received Seldane, provides information on adverse experience incidence for periods of a few days up to six months. The usual dose in these studies was $60 \mathrm{mg}$ twice daily, but in a small number of patients, the dose was as low as $20 \mathrm{mg}$ twice a day, or as high as $600 \mathrm{mg}$ daily.

In controlled clinical studies using the recommended dose of $60 \mathrm{mg}$ b.i.d., the incidence of reported adverse effects in patients receiving Seldane was similar to that reported in patients receiving placebo. (See Table below.)

\section{ADVERSE EVENTS REPORTED IN CLINICAL TRIALS}

\begin{tabular}{|c|c|c|c|c|c|}
\hline \multirow[b]{2}{*}{$\begin{array}{c}\text { Adverse } \\
\text { Event }\end{array}$} & \multicolumn{5}{|c|}{ Percent of Patients Reporting } \\
\hline & $\begin{array}{l}\text { Co } \\
\text { Seldane } \\
M=781\end{array}$ & $\begin{array}{l}\text { Irolled Stu } \\
\text { Placebo } \\
\mathrm{N}=665\end{array}$ & $\begin{array}{l}\text { idies: } \\
\text { Control } \\
N=626 \%\end{array}$ & \begin{tabular}{|l} 
All Clinical \\
Seldane \\
$\mathbf{N}=\mathbf{2 4 6 2}$
\end{tabular} & $\begin{array}{l}\text { Studies:"* } \\
\text { Placebo } \\
\mathrm{N}=1478\end{array}$ \\
\hline \multicolumn{6}{|l|}{ Central Nervous System } \\
\hline $\begin{array}{l}\text { Drowsiness } \\
\text { Headache } \\
\text { Fatigue } \\
\text { Diziness } \\
\text { Nervousness } \\
\text { Weakness } \\
\text { Appetite Increase }\end{array}$ & $\begin{array}{l}9.0 \\
6.3 \\
2.9 \\
1.4 \\
0.9 \\
0.9 \\
0.6\end{array}$ & $\begin{array}{l}8.1 \\
7.4 \\
0.9 \\
1.1 \\
0.2 \\
0.6 \\
0.0\end{array}$ & $\begin{array}{r}18.1 \\
3.8 \\
5.8 \\
1.0 \\
0.6 \\
0.2 \\
0.0\end{array}$ & $\begin{array}{r}8.5 \\
15.8 \\
4.5 \\
1.5 \\
1.7 \\
0.6 \\
0.5\end{array}$ & $\begin{array}{r}8.2 \\
11.2 \\
3.0 \\
1.2 \\
1.0 \\
0.5 \\
0.0\end{array}$ \\
\hline \multicolumn{6}{|l|}{$\begin{array}{l}\text { Gastrointestinal System } \\
\text { Gastrointestinal Distress } \\
\text { (Abdominal distress, } \\
\text { Nausea, Vomiting. }\end{array}$} \\
\hline $\begin{array}{l}\text { Change in Bowel habits) } \\
\text { Eye. Ear, Nose, and Throat }\end{array}$ & 4.6 & 3.0 & 2.7 & 7.6 & 5.4 \\
\hline $\begin{array}{l}\text { Eye, Ear, Nose, and Throat } \\
\text { Dry Mouth/ Nose/Throat }\end{array}$ & 2.3 & 1.8 & 3.5 & 4.8 & 3.1 \\
\hline $\begin{array}{l}\text { Cough } \\
\text { Sore Throat }\end{array}$ & $\begin{array}{l}0.9 \\
0.5\end{array}$ & $\begin{array}{l}0.2 \\
0.3\end{array}$ & $\begin{array}{l}0.5 \\
0.5\end{array}$ & $\begin{array}{l}2.5 \\
3.2\end{array}$ & $\begin{array}{l}1.7 \\
1.6\end{array}$ \\
\hline $\begin{array}{l}\text { Epistaxis } \\
\text { Skin }\end{array}$ & 0.0 & 0.8 & 0.2 & 0.7 & 0.4 \\
\hline \multicolumn{6}{|l|}{$\begin{array}{l}\text { Skin } \\
\text { Eruption (including rash }\end{array}$} \\
\hline and urticaria) or itching & 1.0 & 1.7 & 1.4 & 1.6 & 2.0 \\
\hline
\end{tabular}

"Duration of treatment in "CONTROLLED STUDIES" was usually 7-14 DAYS
$\because$ Duration of treatment in "ALL CLINICAL STUDIES" was up to 6 months.

CONTROL DRUGS: Chlorpheniramine (291 patients), d-Chlorpheniramine (189 patients), Clemastine (146 patients)

In addition to the more frequent side effects reported in clinical trials (See Table), adverse effects have been reported at a lower incidence in clinical trials and/or spontaneously during marketing of Seldane that warrant listing as possibly associated with drug administration. These include: arketing of Seldane that warrant listing as possibly associated with drug administration. These include: alopecia, (hair loss or thinning), anaphylaxis, angioedena chospasm, confusion, depression, galactor dysmenorrhea), musculoskeletal symptoms, nightmares, palpitation, paresthesia, photosensitivity, proIonged QT interval, seizures, sweating, syncope, tachycardia, tremor, urinary frequency, and visual disturbances. In clinical trials, several instances of mild, or in one case, moderate transaminase elevations were seen in patients receiving Seldane. Mild elevations were also seen in placebo treate patients. Marketing experiences include isolated reports of jaundice, cholestatic hepatitis, and hepatitis: is a causal relationship of liver abnormalities to Seldane use clear. OVERDOSAGE

Information concerning possible overdosage and its treatment appears in Full Prescribing Information. DOSAGE AND ADMINISTRATION

The usual dosage for adults and children 12 years and older is $60 \mathrm{mg}$ (1 tablet) twice daily.

Product Information as of June, 1988

MERRELL DOW PHARMACEUTICALS INC

Subsidiary of The Dow Chemical Company

Merrell Dow

PRINTED IN U.S.A

References: 1. Murphy-O'Connor JC. Renton RL. Westlake DM: Comparative trial of two dose regimens of terfenadine in patients with hay fever J Int Med Res 1984:12:333-337. 2. Huther KJ, Renftle G. Barraud N. et al: Inhibitory activity of terfenadine on histamine-induced skin wheals in man. Eur J Clin Pharmacol 1977:12:195-199. 3. Kemp JP. Buckley CE. Gershwin ME, et al: Multicenter, double-blind, placebo-controlled trial of terfenadine in seasonal allergic rhinitis and conjunctivitis. Ann Allergy 1985:54:502-509.4. Backhouse Cl. Brewster BS. Lockhart JDF, et al: Terfenadine in allergic rhinitis. A comparative trial of a new

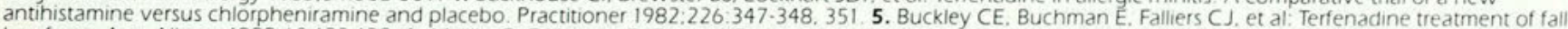

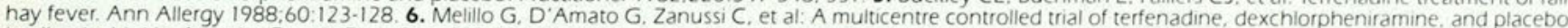

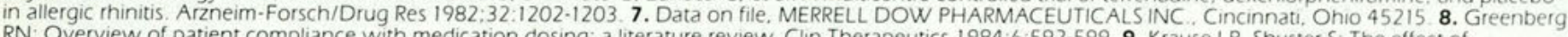
RN: Overview of patient compliance with medication dosing: a literature review. Clin Therapeutics 1984:6:592-599.9. Krause LB. Shuster S: The effect of terfenadine on dermographic wealing. Br J Dermatol 1984:10:73-79. 10. Kemp JP. Falliers CJ. Fox RW. et al: A multicenter, open study of the non-sedating

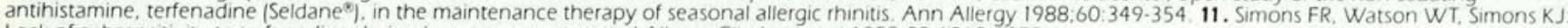
Lack of subsensitivity to terfenadine during long-term treatment. J Allergy Clin Immunol 1988:82:1068-1075 
